\title{
Pelaksanaan Wajib Lapor Ketenagakerjaan Setelah Berlakunya Undang-Undang Nomor 23 Tahun 2014
}

\section{Ni Wayan Winiarti'}

${ }^{1}$ Dinas Tenaga Kerja dan Energi Sumber Daya Mineral Provinsi Bali-Indonesia, E-mail: $\underline{w}$ _winia@yahoo.com

\begin{tabular}{l}
\hline Info Artikel \\
Masuk: 28 Pebruari 2018 \\
Diterima: 5 April 2018 \\
Terbit: 30 April 2019 \\
Keywords : \\
obligation to report, \\
employment, company \\
\\
Dorresponding Author: \\
wiWayan Winiarti, E-mail: \\
10.24843/AC.2019.v04.i01.p12 \\
Kata kunci: \\
wajib lapor, ketenagakerjaan, \\
perusahaan \\
Coo.com
\end{tabular}

\begin{abstract}
Changes to the implementation of the affairs of labor inspection with the enactment of Law Number 23 Year 2014 on Regional Government impact on the implementation and reporting procedures for compulsory labor report in the company, namely: 1) How the implementation of compulsory reporting of employment in the company at the office of the office in charge of manpower in the districts /city? 2) How is the reporting procedure required to report employment in the company following the enactment of Law Number 23 Year 2014? To find and find solutions to the problem formulation to be studied, then in this writing is done by normative legal research methods with the approach of legislation. As regulated in Article 4 paragraph (1) and paragraph (2) of Law Number 7 of 1981 concerning Obligatory Reporting of Employment in the Company, employers or managers of the company shall report in writing any establishment, termination, reestablishment, transfer or dissolve the company to the Minister who is responsible in the field of manpower or appointed official in this matter who is entrusted with the task of supervision in the field of manpower.
\end{abstract}

\begin{tabular}{l} 
Abstrak \\
\hline Perubahan terhadap penyelenggaraan urusan pengawasan \\
ketenagakerjaan dengan berlakunya Undang-Undang Nomor 23 \\
Tahun 2014 tentang Pemerintahan Daerah berdampak pada \\
pelaksanaan dan tata cara pelaporan wajib lapor ketenagakerjaan \\
di perusahaan, yakni: 1) Bagaimanakah pelaksanaan wajib lapor \\
ketenagakerjaan di perusahaan pada kantor dinas yang \\
membidangi ketenagakerjaan di kabupaten/kota? 2) \\
Bagaimanakah tata cara pelaporan wajib lapor ketenagakerjaan di \\
perusahaan setelah berlakunya Undang-Undang Nomor 23 \\
Tahun 2014? Untuk mencari dan menemukan pemecahan atas \\
rumusan masalah yang akan dikaji, maka dalam penulisan ini \\
dilakukan dengan metode penelitian hukum normatif dengan \\
pendekatan perundang-undangan. Sebagaimana diatur dalam \\
Pasal 4 ayat (1) dan ayat (2) Undang-Undang Nomor 7 Tahun \\
1981 tentang Wajib Lapor Ketenagakerjaan di Perusahaan, \\
pengusaha atau pengurus perusahaan wajib melaporkan secara \\
tertulis setiap mendirikan, menghentikan, menjalankan kembali, \\
memindahkan atau membubarkan perusahaan kepada Menteri \\
yang bertanggung jawab dalam bidang ketenagakerjaan atau \\
pejabat yang ditunjuk dalam hal ini yang diserahi tugas \\
pengawasan di bidang ketenagakerjaan.
\end{tabular}




\section{Pendahuluan}

Pengusaha atau pengurus perusahaan wajib melaporkan secara tertulis setiap mendirikan, menghentikan, menjalankan kembali, memindahkan atau membubarkan perusahaan kepada Menteri yang bertanggung jawab dalam bidang ketenagakerjaan atau pejabat yang ditunjuk dalam hal ini yang diserahi tugas pengawasan di bidang ketenagakerjaan. Hal ini berlaku pula bagi suatu perusahaan yang merupakan kantor cabang atau bagian yang berdiri sendiri dari suatu perusahaan. Ketentuan ini diatur dalam Pasal 4 ayat (1) dan ayat (2) Undang-Undang Nomor 7 Tahun 1981 tentang Wajib Lapor Ketenagakerjaan di Perusahaan (selanjutnya disebut Undang-Undang Nomor 7 Tahun 1981).

Dengan berlakunya Undang-Undang Nomor 23 Tahun 2014 tentang Pemerintahan Daerah (selanjutnya disebut Undang-Undang Nomor 23 Tahun 2014) terdapat perubahan penyelenggaraan urusan pemerintahan konkuren yakni urusan pemerintahan yang dibagi antara Pemerintah Pusat dan Daerah Provinsi dan Daerah Kabupaten/Kota. Urusan pengawasan ketenagakerjaan di daerah yang semula diselenggarakan pemerintah daerah kabupaten/kota dan pemerintah daerah provinsi berubah menjadi tersentralistik yakni diselenggarakan pemerintah daerah provinsi.

Perubahan terhadap penyelenggaraan urusan pengawasan ketenagakerjaan tersebut maka berdampak pada pelaksanaan wajib lapor ketenagakerjaan di perusahaan, yakni: 1) Bagaimanakah pelaksanaan wajib lapor ketenagakerjaan di perusahaan pada dinas yang membidangi ketenagakerjaan di kabupaten/kota? 2) Bagaimanakah tata cara pelaporan wajib lapor ketenagakerjaan di perusahaan setelah berlakunya UndangUndang Nomor 23 Tahun 2014?

Penulisan karya ilmiah ini bertujuan untuk melakukan penelitian terhadap permasalahan hukum dan mengembangkan pengetahuan ilmu hukum terkait pelaksanaan wajib lapor ketenagakerjaan di perusahaan setelah berlakunya UndangUndang Nomor 23 Tahun 2014.

Originalitas atau keaslian penelitian merupakan hal penting dalam penelitian hukum. Sebagai pembanding untuk menunjukkan bahwa penelitian yang dilakukan adalah original atau belum pernah dilakukan penelitian sebelumnya, maka penulis mencari beberapa penelitian yang memuat tentang wajib lapor ketenagakerjaan dengan pembahasan rumusan permasalahan yang berbeda diantaranya sebagai berikut:

1) Kondisi Pasar Kerja di Provinsi Bali: Implementasi Undang-Undang Wajib Lapor Ketenagakerjaan di Perusahaan, pada Jurnal Buletin Studi Ekonomi, Vol. 22 No. 2, Agustus 2017, Universitas Udayana yang ditulis oleh A.A.I.N. Marhaeni, I Ketut Sudibia, I.G.W. Murjana Yasa, Ni Nyoman Yuliarmi, Ni Putu Martini Dewi. Adapun tujuan dari penelitian ini adalah untuk menganalisis:

- kondisi pelaporan perusahaan yang ada di Provinsi Bali tentang kesempatan kerja yang ada sesuai dengan Undang-Undang Nomor 7 Tahun 1981.

- Tingkat perkembangan data pencari kerja di Dinas Tenaga Kerja yang melaporkan dirinya sedang mencari kerja di Provinsi Bali. 
- Tingkat perkembangan pencari kerja yang dapat ditempatkan oleh Dinas Tenaga Kerja sebagai perantara di pasar kerja di Provinsi Bali.

2) Sistem Informasi Administrasi Wajib Lapor Ketenagakerjaan di Perusahaan Pada Dinas Sosial Tenaga Kerja dan Transmigrasi Kabupaten Kudus, yang ditulis oleh Tri Wijayanti, Tahun 2014, Universitas Muria Kudus. Tujuan dari penelitian ini adalah untuk mengetahui prosedur pelaporan berdirinya perusahaan yang nantinya digunakan sebagai bahan analisa perancangan system administrasi wajib lapor ketenagakerjaan di perusahaan berbasis web yang mampu menyajikan data secara valid dan akurat.

3) Peran Dinas Tenaga Kerja Dalam Perlindungan dan Pengawasan di Kota Samarinda yang ditulis oleh Jeffri Suradiansyah, Tahun 2016, Universitas Mulawarman. Tujuan dari penelitian ini untuk mengetahui peran Dinas Tenaga Kerja dalam perlindungan dan pengawasan tenaga kerja di Kota Samarinda dengan indikator: monitoring pelaksanaan wajib lapor ketenagakerjaan dan koordinasi dengan pihak lain, serta kendala yang dihadapi dinas tenaga kerja dalam melaksanakan perannya tersebut.

\section{Metode Penelitian}

Untuk mencari dan menemukan pemecahan atas rumusan masalah yang akan dikaji, maka dalam penulisan ini dilakukan dengan metode penelitian hukum normatif dengan pendekatan perundang-undangan. Komponen penelitian hukum normatif mencakup obyek norma hukum sebagai sistem norma, struktur norma hukum, validitas norma, keberdasaran norma, kebersumberan norma, dan konsistensi norma. ${ }^{1}$ Dalam penulisan ini penelitian dilakukan secara sistematik dengan menelaah UndangUndang Nomor 7 Tahun 1981, Undang-Undang Nomor 12 Tahun 2011 tentang Pembentukan Peraturan Perundang-undangan (selanjutnya disebut Undang-Undang Nomor 12 Tahun 2011), Undang-Undang Nomor 23 Tahun 2014, Permenaker RI Nomor: PER.06/MEN/1995, Permenakertrans RI Nomor: PER-14/MEN/IV/2006, Permenaker Nomor 18 Tahun 2017, dan Peraturan Kepala Badan Kepegawaian Negara Nomor 48 Tahun 2015 tentang Pelaksanaan Pengalihan Pegawai Negeri Sipil Daerah Kabupaten/Kota yang menyelenggarakan Pengawasan Ketenagakerjaan Menjadi Pegawai Negeri Sipil Daerah Provinsi (selanjutnya disebut Perka BKN Nomor 48 Tahun 2015) untuk mencari dan menemukan struktur norma hukum, validitas norma, keberdasaran norma, kebersumberan norma, dan konsistensi norma dalam hal pelaksanaan wajib lapor ketenagakerjaan di perusahaan.

Adapun yang menjadi sumber penelitian hukum yakni bahan hukum primer berupa peraturan perundang-undangan dan bahan hukum sekunder berupa literatur penunjang. Dalam penelitian ini, penulis melakukan pengumpulan bahan-bahan hukum dengan melakukan inventarisasi undang-undang, menelusuri buku-buku literatur penunjang terkait, mengkaji atau menelaah isi dari bahan-bahan yang dikumpulkan dan mengutip bahan-bahan yang relevan.

Untuk menganilisis bahan-bahan yang telah dikumpulkan, teknis analisis yang digunakan yakni teknik deskripsi adalah teknik dasar analisis yang berarti

\footnotetext{
${ }^{1}$ Ida Bagus Wyasa Putra, 2015, Filsafat Ilmu:Filsafat Ilmu Hukum, Denpasar, Udayana University Press, hlm. 206.
} 
penggambaran/uraian apa adanya terhadap suatu kondisi atau posisi dari proposisiproposisi hukum atau non hukum. ${ }^{2}$

\section{Hasil dan Pembahasan}

\subsection{Pelaksanaan Wajib Lapor Ketenagakerjaan Di Perusahaan Pada Dinas Yang Membidangi Ketenagakerjaan Di Kabupaten/Kota}

Pelaksanaan wajib lapor ketenagakerjaan di perusahaan selama ini dilaporkan secara tertulis dalam bentuk formulir laporan ketenagakerjaan yang telah disediakan oleh dinas yang membidangi ketenagakerjaan di kabupaten/kota yang membidangi ketenagakerjaan di mana lokasi perusahaan itu berada, sebagaimana diatur dalam Pasal 3 ayat (1) dan Pasal 4 Peraturan Menteri Tenaga Kerja dan Transmigrasi RI Nomor: PER-14/MEN/IV/2006 tentang Tata Cara Pelaporan Ketenagakerjaan di Perusahaan (selanjutnya disebut Permenakertrans RI Nomor: PER-14/MEN/IV/2006). Dengan berlakunya Undang-Undang Nomor 23 Tahun 2014, penyelenggaraan pengawasan ketenagakerjaan telah beralih menjadi urusan pemerintah daerah provinsi.

Undang - Undang Nomor 23 Tahun 2014 mengatur bahwa urusan pemerintahan secara prinsip bersumber dari kekuasaan pemerintahan yang dimiliki oleh Presiden sebagaimana diatur dalam Undang-Undang Dasar Negara Republik Indonesia. Selanjutnya kekuasaan pemerintahan tersebut diuraikan dalam berbagai urusan pemerintahan. ${ }^{3}$ Urusan pemerintahan sebagaimana diatur dalam Pasal 9 ayat (1) Undang-Undang Nomor 23 Tahun 2014 terdiri atas urusan pemerintahan absolut, urusan pemerintahan konkuren dan urusan pemerintahan umum. Urusan bidang tenaga kerja merupakan bagian urusan pemerintahan konkuren yang menjadi kewenangan daerah yakni urusan pemerintahan wajib yang tidak berkaitan dengan pelayanan dasar. Urusan pemerintahan konkuren adalah urusan pemerintahan yang dibagi antara Pemerintah Pusat dan Daerah Provinsi dan Daerah Kabupaten/Kota yang pembagiannya tercantum dalam lampiran Undang-Undang Nomor 23 Tahun 2014. Dari 4 (empat) sub urusan pemerintahan bidang tenaga kerja yang mengalami perubahan sebagaimana tercantum dalam lampiran huruf G Undang-Undang Nomor 23 Tahun 2014, salah satu diantaranya adalah sub urusan pengawasan ketenagakerjaan yang semula diselenggarakan pemerintah daerah kabupaten/kota dan pemerintah daerah provinsi berubah menjadi tersentralistik yakni diselenggarakan pemerintah daerah provinsi. Urusan Pemerintah Pusat dalam sub urusan pengawasan ketenagakerjaan adalah penetapan sistem pengawasan ketenagakerjaan dan pengelolaan tenaga pengawas ketenagakerjaan. Dengan demikian urusan pengawasan ketenagakerjaan tidak lagi diselenggarakan oleh pemerintah daerah kabupaten/kota. Adanya perubahan penyelenggaraan urusan pengawasan ketenagakerjaan di provinsi tersebut maka pengelolaan administrasi pengawasan ketenagakerjaan, yang salah satunya meliputi pelaksanaan wajib lapor ketenagakerjaan di perusahaan menjadi

\footnotetext{
${ }^{2}$ Program Studi Magister (S2) Ilmu Hukum Program Pasca Sarjana Universitas Udayana, 2013, Pedoman Penulisan Usulan Penelitian Tesis dan Penulisan Tesis Program Studi Magister (S2) Ilmu Hukum, Denpasar, hlm. 32.

${ }^{3}$ Dinoroy Marganda Aritonang, 2016, Pola Distribusi Urusan Pemerintah Daerah Pasca Berlakunya Undang-Undang Nomor 23 Tahun 2014 tentang Pemerintahan Daerah, Jurnal Legislasi Indonesia (Indonesia Jurnal of Legislation) Vol.13 No.1 Edisi Maret 2016, hlm. 48.
} 
kewenangan dinas yang membidangi ketenagakerjaan provinsi dalam hal ini pejabat yang diserahi tugas pengawasan di bidang ketenagakerjaan.

Sejak diundangkan dan diberlakukannya Undang-Undang Nomor 23 Tahun 2014 pada tanggal 2 Oktober 2014 maka sebagai akibat pembagian urusan penyelenggaraan pengawasan ketenagakerjaan di daerah provinsi semestinya pelaksanaan wajib lapor ketenagakerjaan di perusahaan kepada dinas yang membidangi ketenagakerjaan di provinsi dapat mulai diberlakukan. Namun hal tersebut belum sepenuhnya dapat diselenggarakan, karena serah terima personel, pendanaan, sarana dan prasarana, serta dokumen sebagai akibat pembagian urusan pemerintahan tersebut dilakukan paling lama 2 (dua) tahun terhitung sejak Undang-Undang Nomor 23 Tahun 2014 diundangkan. Pengalihan personel dalam hal ini pegawai negeri sipil daerah kabupaten/kota yang menyelenggarakan pengawasan ketenagakerjaan dialihkan menjadi pegawai negeri sipil daerah provinsi ditetapkan terhitung mulai tanggal 1 Oktober 2016 berdasarkan Pasal 2 ayat (4) Perka BKN Nomor 48 Tahun 2015. Pengalihan pegawai negeri sipil tersebut dalam kaitannya dengan pelaksanaan wajib lapor ketenagakerjaan di perusahaan adalah mempunyai wewenang untuk melakukan pengawasan dan penegakan hukum terhadap penerapan norma wajib lapor ketenagakerjaan di perusahaan. Demikian pula terhadap pendanaan dan dokumen wajib lapor ketenagakerjaan di perusahaan yang semula diselenggarakan di kabupaten/kota, sehingga pelaksanaan wajib lapor ketenagakerjaan pada dinas yang membidangi ketenagakerjaan provinsi mulai dilaksanakan terhitung mulai tanggal 1 Januari 2017.

Pengertian kewenangan atau authority dalam Black's Law Dictionary adalah "right to exercise powers; to implement and enforce laws; to exact obedience; to command; to judge; control over; jurisdiction; often synonymus with power". Dalam konstruksi ini, kewenangan tidak hanya diartikan sebagai hak untuk melakukan praktik kekuasaan, namun kewenangan juga diartikan untuk menerapkan dan menegakkan hukum; ketaatan yang pasti; perintah; memutuskan; pengawasan; yurisdiksi; atau kekuasaan. Ateng Syafrudin tidak hanya menyajikan konsep tentang kewenangan, tetapi juga konsep tentang wewenang. Unsur-unsur yang tercantum dalam kewenangan, meliputi adanya kekuasaan formal dan kekuasaan yang diberikan oleh undang-undang. Unsur-unsur wewenang yaitu hanya mengenai suatu "onderdeel" (bagian) tertentu dari kewenangan. Indroharto menyajikan pengertian wewenang dalam arti yuridis adalah suatu kemampuan yang diberikan oleh peraturan perundang-undangan yang berlaku untuk menimbulkan akibat-akibat hukum. ${ }^{4}$

Berdasarkan teori kewenangan tersebut maka kewenangan dinas yang membidangi ketenagakerjaan provinsi dalam hal ini pejabat yang diserahi tugas penyelenggaraan pengawasan di bidang ketenagakerjaan untuk pengelolaan administrasi pengawasan ketenagakerjaan, terkait pelaksanaan wajib lapor ketenagakerjaan di perusahaan merupakan kekuasaan yang diberikan oleh undang-undang yakni Undang-Undang Nomor 23 Tahun 2014 dan Undang-Undang Nomor 7 Tahun 1981. Apabila pengusaha atau pengurus perusahaan tidak memenuhi kewajiban untuk membuat dan menyampaikan laporan ketenagakerjaan tersebut dapat dikenakan sanksi

\footnotetext{
${ }^{4}$ H. Salim HS, Erlies Septiana Nurbani, 2014, Penerapan Teori Hukum Pada Penelitian Tesis dan Disertasi, Jakarta, PT Rajagrafindo Persada,hlm. 185-186.
} 
sebagaimana diatur dalam Pasal 10 Undang-Undang Nomor 7 Tahun 1981. Terhadap pelanggaran tersebut maka pegawai pengawas ketenagakerjaan provinsi diberikan wewenang untuk menerapkan dan menegakkan hukum atas ketentuan UndangUndang Nomor 7 Tahun 1981.

Penyelenggaraan pengawasan ketenagakerjaan oleh pemerintah daerah provinsi sebagaimana ditetapkan pembagiannya dalam lampiran huruf G angka 4 UndangUndang Nomor 23 Tahun 2014 merupakan fungsi hukum sebagai sarana pembaharuan masyarakat. Sebagaimana dikemukakan oleh Mochtar Kusumaatmadja, pembaharuan hukum berarti suatu penetapan prioritas tujuan-tujuan yang hendak dicapai dengan mempergunakan hukum sebagai sarana. Hal ini berhubungan dengan adagium yang dikemukakannya "hukum tanpa kekuasaan adalah angan-angan dan kekuasaan tanpa hukum adalah kezaliman" supaya ada kepastian hukum maka hukum harus dibuat secara tertulis sesuai dengan ketentuan yang berlaku dan ditetapkan oleh negara. ${ }^{5}$ Hal ini sejalan dengan tujuan ditetapkannya penyelenggaraan pengawasan ketenagakerjaan di provinsi yakni terciptanya sinergitas kinerja pengawasan ketenagakerjaan di tingkat pusat dan daerah supaya menjadi lebih efektif dan optimal, serta fungsi pengawasan dan penegakan hukum ketenagakerjaan menjadi independen, terpadu, terkoordinasi dan terintegrasi. Sebelumnya kinerja pengawasan ketenagakerjaan di tingkat daerah kabupaten/kota masih dianggap lemah dan belum optimal dikarenakan terbatasnya kualitas, kuantitas dan penyebaran yang tidak merata pegawai pengawas ketenagakerjaan di daerah kabupaten/kota, serta masih sangat sedikit daerah yang menempatkan pengawas ketenagakerjaan ke dalam jabatan fungsional, banyaknya pegawai pengawas ketenagakerjaan yang dimutasi dan beralih fungsi ke instansi lain sehingga berakibat pada kurang efektifnya pelaksanaan pengawasan ketenagakerjaan di daerah.

\subsection{Tata Cara Pelaporan Wajib Lapor Ketenagakerjaan Di Perusahaan Setelah Berlakunya Undang-Undang Nomor 23 Tahun 2014}

Adanya perubahan urusan pengawasan ketenagakerjaan pada dinas yang membidangi ketenagakerjaan di provinsi berdampak pada pengelolaan administrasi pengawasan ketenagakerjaan, salah satunya adalah pelaksanaan tata cara pelaporan ketenagakerjaan di perusahaan. Dalam upaya melaksanakan pembangunan di bidang ketenagakerjaan secara menyeluruh yang meliputi pelatihan dan produktivitas pekerja, penempatan dan perluasan kerja, pembinaan hubungan industrial, perlindungan dan pengawasan tenaga kerja, serta untuk memenuhi tuntutan perkembangan permasalahan ketenagakerjaan yang semakin kompleks diperlukan data dan informasi mengenai gambaran atau kondisi ketenagakerjaan yang ada di perusahaan melalui tata cara pelaporan sistem dalam jaringan (daring) yang disediakan oleh Kementerian Ketenagakerjaan dengan alamat http://wajiblapor.kemnaker.go.id yang bentuk laporannya telah ditetapkan sebagaimana diatur dalam Permenaker Nomor 18 Tahun 2017. Demikian pula waktu pelaporan berkala ditentukan setiap 1 (satu) tahun pada bulan Desember. Tata cara pelaporan ketenagakerjaan sistem daring yang disediakan oleh Kementerian Ketenagakerjaan tersebut merupakan salah satu sub urusan pengawasan ketenagakerjaan Pemerintah Pusat yang diamanatkan Undang-Undang Nomor 23 Tahun 2014 terkait penetapan sistem pengawasan ketenagakerjaan. Sebelum

\footnotetext{
${ }^{5}$ H. Abdul Manan, 2013, Aspek-Aspek Pengubah Hukum,Jakarta, Kencana, hlm.21-22.
} 
dikeluarkannya Permenaker Nomor 18 Tahun 2017, bentuk formulir pelaporan dimaksud, berdasarkan Permenakertrans RI Nomor: PER-14/MEN/IV/2006 diselenggarakan secara cuma-cuma oleh dinas yang membidangi ketenagakerjaan kabupaten/kota, dan waktu pelaporan berkala hanya ditentukan setiap 1 (satu) tahun tanpa menentukan bulan pelaksanaan pelaporan.

Kewajiban untuk melaporkan secara tertulis kondisi atau keadaan ketenagakerjaan di perusahaan sebagaimana diatur dalam Pasal 4 ayat (1) dan ayat (2) Undang-Undang Nomor 7 Tahun 1981, dilaksanakan oleh pengusaha atau pengurus perusahaan (termasuk perusahaan yang merupakan kantor cabang atau bagian yang berdiri sendiri dari suatu perusahaan) kepada Menteri yang bertanggung jawab dalam bidang ketenagakerjaan atau pejabat yang ditunjuk dalam hal ini yang diserahi tugas pengawasan di bidang ketenagakerjaan, selambat-lambatnya dalam jangka waktu 30 (tiga puluh) hari setelah perusahaan mulai melakukan kegiatan operasional dan atau memperoleh izin usaha, mulai menjalankan kembali kegiatan perusahaan yang telah dihentikan sebelumnya, memindahkan tempat kedudukan dan atau lokasi perusahan atau mengalihkan pemiliknya, dan selambat-lambatnya dalam jangka waktu 30 (tiga puluh) hari sebelum menghentikan kegiatan usaha perusahaan lebih dari satu tahun namun bukan bermaksud untuk membubarkan baik karena kemauan sendiri maupun menurut peraturan perundang-undangan yang berlaku, menghentikan kegiatan perusahaan untuk selama-lamanya. Yang dimaksud dengan pejabat yang ditunjuk oleh Menteri adalah pejabat yang diserahi tugas pengawasan di bidang ketenagakerjaan yakni dinas yang membidangi ketenagakerjaan di provinsi. Selanjutnya dalam ketentuan Pasal 9 Undang-Undang Nomor 7 Tahun 1981 memuat ketentuan bahwa Menteri mengatur tata cara pelaporan dan menetapkan bentuk laporan yang memuat keterangan dimaksud, yang mana tertuang dalam suatu Permenaker Nomor 18 Tahun 2017. Kewajiban melaporkan ketenagakerjaan ini dilakukan secara periodik atau berkala setiap tahun, guna memperoleh data keadaan tenaga kerja secara berkesinambungan.

Sebagaimana diatur dalam ketentuan Pasal 1 Undang-Undang Nomor 7 Tahun 1981 yang dimaksud dengan perusahaan dalam hal ini adalah tiap bentuk usaha yang mempekerjakan pekerja/buruh dengan tujuan mencari keuntungan atau tidak, baik milik swasta maupun milik negara. Pengusaha adalah orang, persekutuan atau badan hukum yang menjalankan suatu perusahaan milik sendiri; orang, persekutuan atau badan hukum yang secara berdiri sendiri menjalankan perusahaan bukan miliknya; orang, persekutuan atau badan hukum yang berada di Indonesia mewakili perusahaan milik sendiri dan menjalankan perusahaan bukan miliknya. Pengurus perusahaan merupakan orang yang ditunjuk untuk memimpin suatu perusahaan.

Adapun bentuk atau format laporan ketenagakerjaan sebagaimana diatur dalam Permenaker Nomor 18 Tahun 2017, memuat keterangan pelaporan keadaan ketenagakerjaan di perusahaan sebagai berikut:

a. Tata cara registrasi wajib lapor ketenagakerjaan dengan mengisi identitas pengguna.

b. Formulir laporan sesudah mendirikan, menjalankan kembali, atau memindahkan perusahaan dengan mengisi keadaan perusahaan, keadaan tenaga kerja, perencanaan tenaga kerja, pelatihan, kesempatan kerja, persyaratan kerja, waktu kerja waktu istirahat, perlindungan tenaga kerja (pengupahan, jaminan sosial, 
kelembagaan), hubungan industrial, keselamatan kesehatan kerja (K3) dan kolom dialog.

c. Formulir laporan sebelum memindahkan, menghentikan atau membubarkan perusahaan dengan mengisi formulir yang tersedia.

Laporan ketenagakerjaan yang disampaikan oleh pengusaha atau pengurus perusahaan merupakan bahan informasi resmi bagi pemerintah dalam menetapkan kebijaksanaan dalam bidang ketenagakerjaan meliputi peningkatan perluasan kesempatan kerja, pembinaan hubungan industrial di perusahaan dan perlindungan tenaga kerja. Pengusaha yang telah menyampaikan pelaporan ketenagakerjaan secara manual kepada dinas provinsi yang membidangi ketenagakerjaan wajib melaporkan kembali secara daring paling lama 1 (satu) tahun sejak Permenaker Nomor 18 Tahun 2017 diundangkan.

Terdapat 5 (lima) pengguna sistem daring wajib lapor ketenagakerjaan yakni; pengusaha atau pengurus, pengawas ketenagakerjaan, administrator sistem, Kepala Dinas Provinsi dan Kepala Dinas Kabupaten Kota yang menyelenggarakan urusan pemerintahan di bidang ketenagakerjaan. Pengoperasian wajib lapor ketenagakerjaan sistem daring dilakukan oleh administrator sistem di mana pada tingkat kementerian oleh Sekretaris Direktorat Jenderal yang membidangi pengawasan ketenagakerjaan dan pada tingkat provinsi oleh kepala dinas yang membidangi ketenagakerjaan atau bagian yang membidangi pengawasan ketenagakerjaan. Selanjutnya administrator sistem pada dinas provinsi membuat akun untuk kepala dinas yang membidangi ketenagakerjaan daerah kabupaten/kota.

Data wajib lapor ketenagakerjaan digunakan sebagai bahan perumusan kebijakan tingkat nasional, daerah provinsi dan daerah kabupaten/kota serta bahan penyusunan rencana kerja unit dan rencana kerja pengawas ketenagakerjaan. Melalui Badan Perencanaan dan Pengembangan Ketenagakerjaan cq Pusat Data dan Informasi Ketenagakerjaan, jaringan dan basis data sistem wajib lapor ketenagakerjaan ini dikelola dan selanjutnya sistem ini dapat diakses oleh unit eselon I di Kementerian Ketenagakerjaan. Sistem daring yang telah dibangun pada Direktorat Jenderal Pembinaan Pengawasan Ketenagakerjaan sebagai unit eselon I wajib dintegrasikan dengan sistem wajib lapor ketenagakerjaan. Demikian pula bagi dinas provinsi yang telah memiliki sistem daring wajib lapor ketenagakerjaan sebelum diundangkannya Permenaker Nomor 18 Tahun 2017 harus mengintegrasikan dengan sistem daring wajib lapor ketenagakerjaan Kementerian Ketenagakerjaan. Berdasarkan permintaan kepala dinas yang membidangi ketenagakerjaan di daerah kabupaten/kota, maka dinas provinsi harus memberikan akses data wajib lapor ketenagakerjaan dari perusahaan yang berada di wilayah daerah kabupaten/kota yang bersangkutan.

Pengoperasian wajib lapor ketenagakerjaan sistem daring dilakukan oleh administrator sistem pada tingkat provinsi oleh kepala dinas yang membidangi ketenagakerjaan atau bagian yang membidangi pengawasan ketenagakerjaan tentunya harus menganggarkan kebutuhan akan sarana dan prasarana seperti pengadaan komputer dan kelengkapannya yang dikhususkan untuk pemanfaatan dan pengelolaan data wajib lapor ketenagakerjaan di perusahaan. Demikian pula tenaga yang ditunjuk sebagai administrator sistem pengoperasian wajib lapor ketenagakerjaan sistem daring, membutuhkan pelatihan melalui pendampingan dari 
Kementerian Ketenagakerjaan pada Direktorat Jenderal yang membidangi pengawasan ketenagakerjaan. Untuk itu diperlukan petunjuk pelaksanaan dan petunjuk teknis yang dijadikan dasar dalam pengadaan sarana dan prasarana wajib lapor ketenagakerjaan sistem daring serta penunjukan dan pelatihan tenaga/pegawai sebagai administrator sistem. Dalam pemberian akses data wajib lapor ketenagakerjaan sistem daring atas permintaan kepala dinas yang membidangi ketenagakerjaan di daerah kabupaten/kota, maka dinas provinsi berkewajiban memberikan petunjuk pelaksanaannya melalui pelatihan atau pendampingan. Dinas yang membidangi ketenagakerjaan di provinsi dan kabupaten/kota mensosialisasikan kepada pengusaha dan atau pengurus perusahaan bahwa urusan pengawasan ketenagakerjaan diselenggarakan oleh dinas yang membidangi ketenagakerjaan di provinsi sehingga salah satu pengelolaan administrasi ketenagakerjaan yakni wajib lapor ketenagakerjaan di perusahaan melalui sistem daring. Pemerintah Pusat dalam hal ini Kementerian Ketenagakerjaan RI agar melakukan pelatihan dan pendampingan pada pengguna wajib lapor ketenagakerjaan sistem daring sehingga pemanfaatan dan pengelolaan administrasi pengawasan ketenagakerjaan berjalan secara efektif dan efisien. Dengan demikian, apabila kesemua hal tersebut telah dipenuhi maka tujuan yang hendak dicapai dari pelaporan ketenagakerjaan sistem daring dapat terpenuhi sehingga selain data tersebut memang benar-benar dibutuhkan juga bermanfaat bagi pengguna sistem daring.

\section{Kesimpulan}

Pelaksanaan wajib lapor ketenagakerjaan di perusahaan tidak lagi diselenggarakan pada dinas yang membidangi ketenagakerjaan di kabupaten/kota dengan adanya perubahan penyelenggaran pengawasan ketenagakerjaan pada dinas yang membidangi ketenagakerjaan di provinsi berdasarkan Undang-Undang Nomor 23 Tahun 2014.

Tata cara pelaporan wajib lapor ketenagakerjaan di perusahaan setelah berlakunya Undang-Undang Nomor 23 Tahun 2014 dilakukan melalui sistem daring yang disediakan oleh Kementerian Ketenagakerjaan dengan alamat http://wajiblapor.kemnaker.go.id yang bentuk laporannya telah ditetapkan sebagaimana diatur dalam Permenaker Nomor 18 Tahun 2017.

\section{Daftar Pustaka}

\section{Buku}

Dyah Ochtorina Susanti, A'an Efendi, 2014, Penelitian Hukum (Legal Research), Jakarta, Sinar Grafika.

H. Salim HS, Erlies Septiana Nurbani, 2014, Penerapan Teori Hukum Pada Penelitian Tesis dan Disertasi, Jakarta, PT Rajagrafindo Persada.

H. Abdul Manan, 2013, Aspek-Aspek Pengubah Hukum,Jakarta, Kencana.

Ida Bagus Wyasa Putra, 2015, Filsafat Ilmu:Filsafat Ilmu Hukum, Denpasar, Udayana University Press.

Munir Fuady, 2013, Teori-Teori Besar (Grand Theory) Dalam Hukum, Jakarta, Kencana Prenamedia Group. 
Program Studi Magister (S2) Ilmu Hukum Program Pasca Sarjana Universitas Udayana, 2013, Pedoman Penulisan Usulan Penelitian Tesis dan Penulisan Tesis Program Studi Magister (S2) Ilmu Hukum, Denpasar.

Philipus M. Hadjon dan Tatiek Sri Djatmiati, 2014, Argumentasi Hukum, Yogyakarta, Gadjah Mada University Press.

Peter Mahmud Marzuki, 2013, Penelitian Hukum Edisi Revisi, Jakarta, Kencana Prenamedia Group.

Sabian Utsman, 2014, Metodologi Penelitian Hukum Progresif, Yogyakarta, Pustaka Pelajar.

\section{$\underline{\text { Jurnal }}$}

Dinoroy Marganda Aritonang, 2016, Pola Distribusi Urusan Pemerintah Daerah Pasca Berlakunya Undang-Undang Nomor 23 Tahun 2014 tentang Pemerintahan Daerah, Jurnal Legislasi Indonesia (Indonesia Jurnal of Legislation) Vol.13 No.1 Edisi Maret 2016, http://ditjenpp.kemenkumham.go.id, diakses tanggal 7 April 2017.

\section{Peraturan Perundangan}

Undang-Undang Nomor 7 Tahun 1981 tentang Wajib Lapor Ketenagakerjaan di Perusahaan

Undang-Undang Nomor 12 Tahun 2011 tentang Pembentukan Peraturan Perundangundangan

Undang-Undang Nomor 23 Tahun 2014 tentang Pemerintahan Daerah

Permenaker RI Nomor: PER.06/MEN/1995 tentang Tata Cara Pelaporan Ketenagakerjaan di Perusahaan

Peraturan Menteri Tenaga Kerja dan Transmigrasi RI Nomor: PER-14/MEN/IV/2006 tentang Tata Cara Pelaporan Ketenagakerjaan di Perusahaan

Peraturan Menteri Ketenagakerjaan RI Nomor 18 Tahun 2017 tentang Tata Cara Wajib Lapor Ketenagakerjaan di Perusahaan Dalam Jaringan

Peraturan Kepala Badan Kepegawaian Negara Nomor 48 Tahun 2015 tentang Pelaksanaan Pengalihan Pegawai Negeri Sipil Daerah Kabupaten/Kota yang menyelenggarakan Pengawasan Ketenagakerjaan Menjadi Pegawai Negeri Sipil Daerah Provinsi 